AGRICULTURE AND BIOLOGY JOURNAL OF NORTH AMERICA

ISSN Print: 2151-7517, ISSN Online: 2151-7525, doi:10.5251/abjna.2013.4.3.166.174

(C) 2013, ScienceHuß, http://www.scihub.org/ABJNA

\title{
Phosphorus fixing capacity of a volcanic soil on the slope of mount Cameroon
}

\author{
Aaron S. Tening ${ }^{*}{ }^{1}$, Josepha N. Foba-Tendo ${ }^{1}$, Susan Y. Yakum-Ntaw ${ }^{1}$ and Frederic \\ Tchuenteu $^{2}$ \\ ${ }^{1}$ Department of Chemistry, University of Buea, P.O. Box 63, Buea, Cameroon \\ ${ }^{2}$ Institute of Agricultural Research for Development, Ekona, PMP 25, Buea, Cameroon \\ ${ }^{\star}$ Corresponding Author (E-mail: suhtening@yahoo.com)
}

\begin{abstract}
The volcanic soils on the slope of mount Cameroon are deficient in available phosphorus (P) resulting in low productivity. Excess $P$ could be a threat to the aquatic environment. There is therefore need to monitor the P-fixing capacity of these soils with depth. The transformation of applied $\mathrm{P}$ in soils from different horizons were examined after treatments with different $\mathrm{P}$ rates $(0$, 20, 60 and $180 \mathrm{mg} \mathrm{P} \mathrm{L}^{-1}$ ) and incubation periods (one, three, seven, 14 and 28 days) under laboratory conditions. Phosphorus was extracted on each treatment combination to determine the amount of $\mathrm{P}$ fixed. Phosphorus recovered increased with added $\mathrm{P}$. Phosphorus fixed increased with added $\mathrm{P}$ and depth throughout the incubation period. The soil showed a high $\mathrm{P}$ fixing capacity throughout the different horizons with $\mathrm{P}$ fixed varying between $57-99 \%$ in the upper horizons and $90-100 \%$ in the lower horizons. More than $90 \%$ of added $\mathrm{P}$ was fixed after one day of incubation. This therefore reduces the threat of eutrophication. Phosphorus fixed correlated positively with clay and $\mathrm{pH}$, and negatively with organic carbon and available $\mathrm{P}$. Clay had a significant $(\mathrm{p}<0.05)$ positive correlation with $\mathrm{pH}$ values. Clay and $\mathrm{pH}$ could therefore be responsible for $\mathrm{P}$-fixation in this soil.
\end{abstract}

Key words: Phosphorus, volcanic soil, fixing capacity, depth, mount Cameroon

\section{INTRODUCTION}

Phosphorus is an essential plant nutrient and its deficiency limits plant growth (Foth, 1984). Phosphorus enhances a good development of the root system particularly of the fibrous and lateral rootlets, a route through which the other nutrients can be made available to plants (Brady, 1984).

Phosphorus deficiency in plants constitutes the second most important soil fertility problem throughout the world (Sanchez and Salinas, 1981). Sanchez (1976), Le Mare, (1991), Sattell and Morris (1992), and Doula et al. (1996) have all indicated that $P$ is the second most limiting element in the Alfisols, Oxisols, and Ultisols of tropical and subtropical Africa, Asia, and South America. Phosphorus deficiency in such soils is often exacerbated by a high capacity to fix (adsorb and/or precipitate) $\mathrm{P}$, making it less available to crops (Quang et al., 1996). Phosphorus nutrition of crop plants is more of a soil problem and a higher dose of $P$ is necessary for soils having high $\mathrm{P}$-fixing capacities. Phosphorus fixation capacity of soils is of considerable importance in determining the requirements for applied $P$. The fixation capacity of a soil may also be indicative of possible adverse environmental effects. The $\mathrm{P}$ fixation in soils depends upon soil $\mathrm{pH}$, organic matter content and mineralogical constitution of the colloids (Pardon and Guadalix, 1990). Owusu-Bennoah and Acquaye (1989) studied the phosphate sorption characteristics of some Ghanaian soils and found that the phosphate sorption maxima were highly correlated with the soil properties in the order: $\mathrm{Al}_{2} \mathrm{O}_{3}$, clay content, free $\mathrm{Fe}_{2} \mathrm{O}_{3}$ and organic carbon. Morel et al. (1989) evaluated the phosphate fixing capacity of soils by the isotopic exchange techniques in northeast France and reported that there was a significant correlation between amount of phosphorus fixed, $\mathrm{pH}$, exchangeable cations, clay content and soluble phosphate. Soon (1990) studied the solubility and retention of phosphates in soils of north western Canada prairies and found that correlations showed between $\mathrm{P}$ sorption capacity and clay content.

Koenig et al. (2000) observed that sampling depths of 10 and $15 \mathrm{~cm}$ frequently resulted in lower $P$ fertilizer recommendation than those of $30-\mathrm{cm}$ depth. 
Sampling depth is therefore an important consideration in routine soil sampling for the purpose of making fertilizer recommendation. Soil $P$ movement is very slow and there is marked retention of added soluble $P$ due to the presence of calcium $(\mathrm{Ca})$, aluminium $(\mathrm{Al})$, iron $(\mathrm{Fe})$ and magnesium $(\mathrm{Mg})$ ions, particularly in tropical soils (lyamuremye and Dick, 1996). There is also low solubility of naturally occurring phosphates thus a low availability of native $P(0.01 \%)$ and low concentration of $P$ in soil solutions at any given time (Brady, 1984; Foth, 1984; Hedley et al., 1996).

Because phosphate fertilizer is one of the most expensive inputs for the production of crops, it is essential not only to know the most cost-effective $P$ application rates and methods but also the long-term effects of the added $P$ in the soil. Excess phosphates are contaminants in soil and water. Phosphates in most soils are held by fixation and not easily leached. However in sandy soils that contain little clay, iron and aluminium oxides or organic matter, phosphates can leach through these soils and impact ground water quality (Sparks, 1995). The greatest concern for $P$ is the contamination of streams and lakes via runoff and erosion. Phosphorus water contamination leads to eutrophication and death of aquatic life. The nutrient enriched water is difficult to treat and encourages the growth of algae which produces odour (Sparks, 1995).

Phosphorus fixation studies in relation to time, depth and $\mathrm{P}$ concentrations, which can help us to evaluate the retention capacity of any given soil, is a vital first step in the contribution to providing sufficient $P$ to plants and avoiding waste of resources and subsequently eutrophication. Very little information is available on the profile distribution of $P$ and its fixing capacity on the volcanic soils of Cameroon. This study was undertaken to evaluate the effect of different concentrations of potassium dihydrogen phosphate $\left(\mathrm{KH}_{2} \mathrm{PO}_{4}\right)$ on the $\mathrm{P}$-fixation capacity of soils from different depths under laboratory conditions.

\section{MATERIALS AND METHODS}

Five soil samples were collected from a soil profile of a volcanic soil on the slope of mount Cameroon (Lat $04^{\circ} 09.845^{\prime} \mathrm{N}$; Lon $009^{\circ} 17.634^{\prime} \mathrm{E}$ ). The location was selected on the basis of the agricultural practices. This area is currently established with a banana plantation and receives phosphorus fertilization. A profile pit of $120 \times 90 \mathrm{~cm}$ surface dimension was dug and the different horizons identified. The soil samples were collected from the different horizons, starting from the bottom of the profile pit in order to avoid contamination of samples with soils of overlying horizons.

Each soil sample was air-dried and ground in a wooden mortar to pass through a 2-mm sieve. The soils were analysed for $\mathrm{pH}$ (soil:water ratio of 1:2.5), organic carbon, calcium, magnesium, potassium, sodium, exchange acidity and particle-size distribution by methods largely described by Jackson (1958).

Five gram $(5 \mathrm{~g})$ of the air dried soil samples was weighed from each treatment, represented by the five soil depths $(0-15 \mathrm{~cm}, 15-46 \mathrm{~cm}, 46-92 \mathrm{~cm}, 92-$ $145 \mathrm{~cm}$ and $145-182 \mathrm{~cm}$ depth), into plastic cups. Twenty-five millilitres $(25 \mathrm{~mL})$ of each of the different concentrations $\left(0 \mathrm{mg} \mathrm{L}^{-1}, 20 \mathrm{mg} \mathrm{L}^{-1}, 60 \mathrm{mg} \mathrm{L}^{-1}\right.$ and $180 \mathrm{mg} \mathrm{L}^{-1}$ ) of $\mathrm{P}$ solutions, in the form of potassium dihydrogen phosphate $\left(\mathrm{KH}_{2} \mathrm{PO}_{4}\right)$ was added to each plastic cup as per treatment. The whole experiment was carried out in two sets and the mean data have been presented. Three drops of chloroform was added to each cup to prevent microbial growth. The cups were plugged and the samples were then incubated at room temperature $\left(25^{\circ} \mathrm{C}\right)$ for one, three, seven, 14 and 28 days making a total of 200 samples (five soil depths $x$ four concentrations $x$ five incubation periods $x$ two replicates). Using a reciprocal shaker, the samples were shaken at 120 oscillations per minute for one-hour. Two shakings were made at six hours interval per day. The samples were filtered after one, three, seven, 14 and 28 days of incubation using a Whatmann No 1 filter paper. The amount of $\mathrm{P}$ left in the clear solution was determined using the phospho-molybdenum blue method (Murphy and Riley, 1962). The P fixed (Pf) and percent $P$ fixed (\%Pf) were calculated using the following formulae:

$$
\begin{aligned}
& \mathrm{Pf}=\mathrm{PI}-\mathrm{Px} \\
& \% \mathrm{Pf}=[(\mathrm{PI}-\mathrm{Px}) / \mathrm{P} 1] \times 100
\end{aligned}
$$

where $P f$ was the $P$ fixed, $P x$ was $P$ in the $x^{\text {th }}$ fraction of the $P$ treatment (i.e. 0, 20, 60 and $\left.180 \mathrm{mg} \mathrm{L}^{-1}\right)$ and $\mathrm{PI}$ was the applied $\mathrm{P}$ level (i.e., 0, 20, 60 and $180 \mathrm{mg} \mathrm{L}^{-1}$ ).

Native adsorbed $\mathrm{P}$ was not determined or included in the fixation measurement.

The data from the experiments were analyzed using the statistical package from social science (SPSS-17) and Excel-2007 tools. Soil data was subjected to correlation analysis to establish the relationship 
between $\mathrm{P}$ fixed and some soil properties, and $\mathrm{P}$ fixed and depth.

\section{RESULTS AND DISCUSSION}

Soil Physicochemical Properties: The soils were moderately acidic. The soil $\mathrm{pH}$ ranged from 5.7-6.1 and increased with depth (Table 1). Tening et al. (2008) and Ngane et al. (2012) also observed low pH values in some soils from South-western Cameroon. Organic carbon and total $\mathrm{N}$ decreased from $4.0 \%$ and $0.27 \%$, respectively, in the surface horizon $(0-15 \mathrm{~cm})$ to $1.0 \%$ and $0.08 \%$, respectively, in the deepest horizon $(145-182 \mathrm{~cm})$. Clay content of the soil ranged from $16.7 \%$ to $25.3 \%$ and generally increased with depth. Available $\mathrm{P}$ varied widely between $8-148 \mathrm{mg}$ $\mathrm{kg}^{-1}$ and decreased with depth. The very high values could be associated to the fact that this soil had been fertilized with $P$ and movement of $P$ in the soil is very slow (Brady, 1984; Koenig et al., 2000). Exchangeable calcium decreased from 12.83 to 4.87 $\mathrm{cmol} \mathrm{kg}{ }^{-1}$ with depth. It was high for the first two horizons and adequate for the rest. Exchangeable potassium ranged from 0.19 to $2.77 \mathrm{cmol} \mathrm{kg}^{-1}$ and decreased with depth. This could be associated to the fact that the soil had been fertilized. Exchangeable sodium decreased from 0.27 to 0.009 $\mathrm{cmol} \mathrm{kg}{ }^{-1}$ with depth and was found to be low for all horizons.

Phosphorus Fixation: The relationship between percent $P$ fixed and amount of $P$ recovered at various concentrations of added $\mathrm{P}$ with depth at different incubation times is shown in Table 2. The soil showed a high $\mathrm{P}$ fixing capacity throughout the different horizons with percent $P$ fixed varying between $57-99 \%$ in the upper horizons and $90-100 \%$ in the lower horizons. This was not unusual as the soils from the lower horizons had high clay content $(>24 \%)$, low available $\mathrm{P}$ content $\left(<12 \mathrm{mg} \mathrm{kg}^{-1}\right)$ and low organic $C$ content $(<2 \%)$.

The low P-fixing capacity of the soils from the upper horizons as compared to those from the lower horizons may be due to presence of more organic matter in the soil of the upper horizons. Organic molecules released on decomposition of organic matter form complexes with $\mathrm{Fe}$ and $\mathrm{Al}$ in the soil thereby blocking the sites which are mainly responsible for fixation of phosphorus in the soil (Juo and Fox, 1977; Subramanian and Kumaraswamy, 1989; Brouwere et al., 2003; Ghosal et al., 2011). Banik et al. (2006) also showed that addition of organic manure markedly increased the availability of phosphorus in the soil. This increase in phosphorus availability in the soil was found to be statistically significant over control treatment and also over treatments with inorganic fertilizers.

When no $P$ was added, fluctuating amounts of $P$ were recovered which could be due to the fact that fixation in these soil could be mainly adsorption and hence Equilibrium could either shift to the left or right depending on the amount of $P$ present. This could lead to a sporadic release and fixation of $P$ in these soils.

Fixation generally increased with the amount of added $P$ and time. The lowest fixation was obtained when $20 \mathrm{mg} \mathrm{L}^{-1}$ of $\mathrm{P}$ was added for the upper horizons $(<100 \mathrm{~cm})$, which constitute the rooting zone (Figure 1). When $20 \mathrm{mg} \mathrm{L}^{-1}$ of $P$ was applied, fixation was very strong from the beginning and did not change much within 14 days. After which the percent $P$ fixed decreased for the upper horizons (Figure 2). Varying trends were observed at higher rates of $P$. This indicates that the fixation trend depends on the amount of available $P$ and the amount of $P$ added. When available $P$ is high, less $P$ is fixed and vice versa.

The percent $P$ fixed was also correlated with some soil properties at various incubation periods and concentrations of applied $P$ (Table 3). Percent $P$ fixed had a negative correlation with organic carbon, contrary to previous studies on tropical savannah soils of Western Nigeria (Ayodele and Agboola, 1981) and the red and lateritic soils of West Bengal (Dolui and Gangopadhyay, 1984). The negative correlation could be associated to the fact that the soil could be made up mainly of decomposing organic materials from citrates, tartrates, acetates, oxalates and malonates which give rise to anions that form highly stable complex ions with $\mathrm{Ca}^{2+}, \mathrm{Fe}^{3+}$ and $\mathrm{Al}^{3+}$ and have greater affinity for these cations than does the phosphate ion (Donuhue et al., 1971). The organic matter could also be made up mainly of fulvic acids which form loosely bound compounds thus $P$ could be easily released with time (Le Mare, 1991). Awad and Al-Obaidy (1989) and Dhargawe et al. (1991) have found that addition of organic matter to soils increases the availability of $P$. 
Agric. Biol. J. N. Am., 2013, 4(3): 166-174

Table 1. Some physicochemical properties of the soil studied.

\begin{tabular}{|c|c|c|c|c|c|c|c|c|c|c|c|c|c|c|c|c|}
\hline Depth & $\begin{array}{l}\mathrm{pH} \\
\left(\mathrm{H}_{2} \mathrm{O}\right)\end{array}$ & $\begin{array}{l}\text { Org. } \\
\mathrm{C}\end{array}$ & $\begin{array}{l}\text { Total } \\
\mathrm{N}\end{array}$ & $\mathrm{C} / \mathrm{N}$ & Avail. P & $\mathrm{Ca}$ & $\mathrm{Mg}$ & $\mathrm{K}$ & $\mathrm{Na}$ & $\begin{array}{l}\text { Exch. } \\
\text { acidity }\end{array}$ & ECEC & $\begin{array}{l}\text { Base } \\
\text { sat. }\end{array}$ & Sand & Silt & Clay & $\begin{array}{l}\text { Text. } \\
\text { class }\end{array}$ \\
\hline$(\mathrm{cm})$ & & $\longrightarrow$ & & & $\left(\mathrm{mg} \mathrm{kg}^{-1}\right)$ & & & $\mathrm{cmol} \mathrm{k}$ & & & & & $\%$ & & & \\
\hline $0-15$ & 5.7 & 4.0 & 0.27 & 14.8 & 143 & 12.83 & 2.67 & 2.77 & 0.27 & 0.06 & 18.65 & 99.68 & 58.9 & 21.9 & 19.2 & SaL \\
\hline $15-46$ & 5.6 & 2.7 & 0.26 & 10.4 & 140 & 6.56 & 1.64 & 1.21 & 0.11 & 0.04 & 9.56 & 99.58 & 26.0 & 57.3 & 16.7 & SiL \\
\hline $46-92$ & 5.9 & 2.0 & 0.21 & 9.5 & 105 & 6.82 & 3.54 & 0.85 & 0.11 & 0.04 & 11.36 & 99.65 & 20.2 & 59.5 & 20.3 & SiL \\
\hline $92-145$ & 6.0 & 1.6 & 0.11 & 14.5 & 11 & 4.46 & 2.56 & 0.50 & 0.06 & 0.03 & 7.64 & 99.61 & 24.3 & 51.1 & 24.6 & SiL \\
\hline $145-182$ & 6.1 & 1.0 & 0.08 & 12.5 & 8 & 4.87 & 1.52 & 0.19 & 0.09 & 0.00 & 6.67 & 100 & 20.6 & 54.1 & 25.3 & SiL \\
\hline
\end{tabular}

${ }^{*}$ SaL=Sandy loam; SiL=Silt loam

Table 2. Amount of $\mathbf{P}$ fixed by soils from different depths following incubation for one to 28 days.

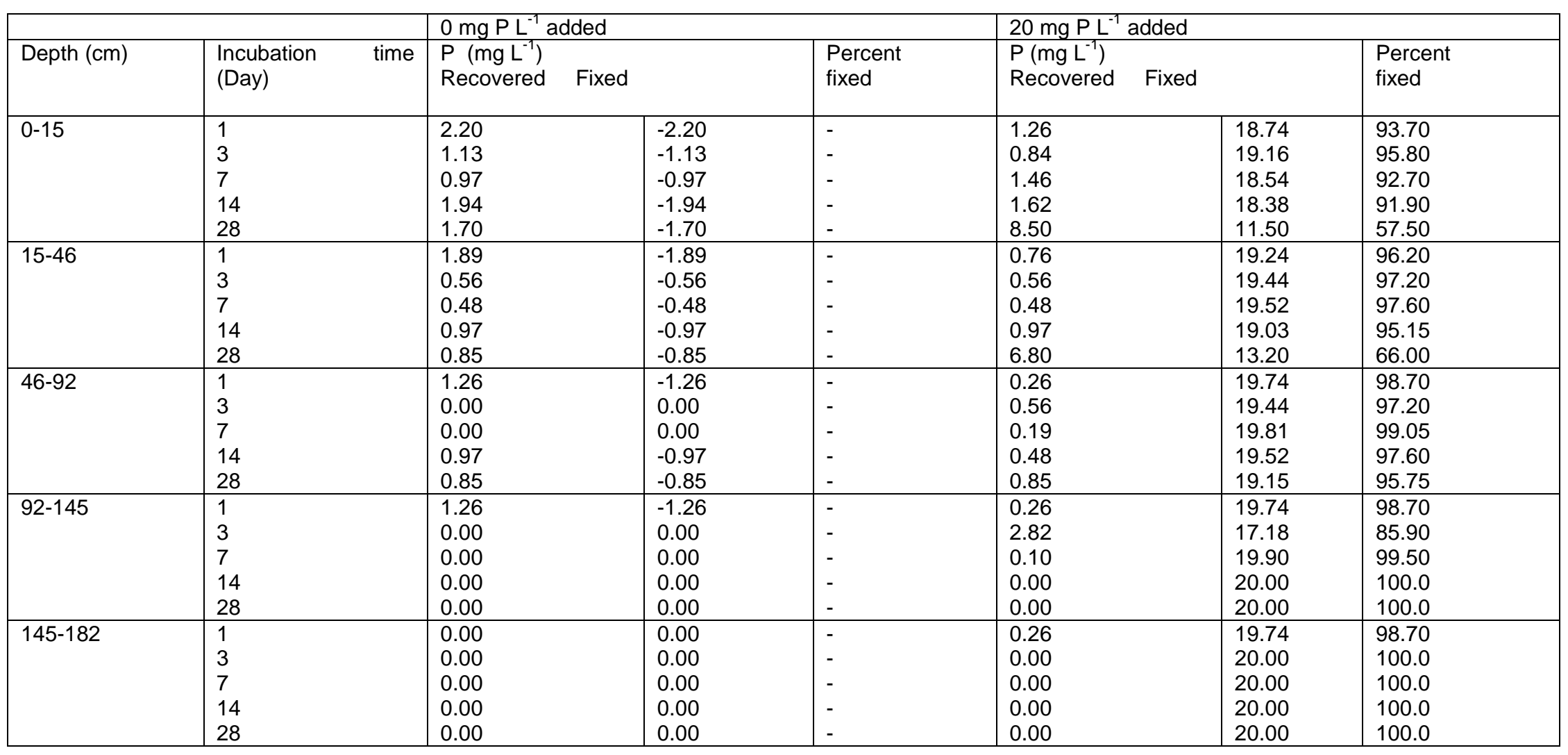


Agric. Biol. J. N. Am., 2013, 4(3): 166-174

Table 2. (Continued).

\begin{tabular}{|c|c|c|c|c|c|c|c|}
\hline & & $60 \mathrm{mg} \mathrm{P} \mathrm{L}^{-1} \mathrm{a}$ & & & $180 \mathrm{mg} \mathrm{P} \mathrm{L}$ & & \\
\hline Depth (cm) & $\begin{array}{l}\text { Incubation time } \\
\text { (Day) }\end{array}$ & $\begin{array}{l}\mathrm{P}\left(\mathrm{mg} \mathrm{L}^{-1}\right) \\
\text { Recovered }\end{array}$ & & $\begin{array}{l}\text { Percent } \\
\text { fixed }\end{array}$ & $\begin{array}{l}\mathrm{P}\left(\mathrm{mg} \mathrm{L}^{-1}\right) \\
\text { Recovered }\end{array}$ & & $\begin{array}{l}\text { Percent } \\
\text { fixed }\end{array}$ \\
\hline $0-15$ & $\begin{array}{l}1 \\
3 \\
7 \\
14 \\
28\end{array}$ & $\begin{array}{l}6.30 \\
1.70 \\
0.48 \\
1.74 \\
1.70\end{array}$ & $\begin{array}{l}53.70 \\
58.30 \\
59.52 \\
58.26 \\
58.30\end{array}$ & $\begin{array}{l}89.50 \\
97.17 \\
99.20 \\
97.10 \\
97.17\end{array}$ & $\begin{array}{l}15.75 \\
9.58 \\
7.99 \\
7.26 \\
4.67\end{array}$ & $\begin{array}{l}164.25 \\
170.42 \\
172.01 \\
172.74 \\
175.33\end{array}$ & $\begin{array}{l}91.25 \\
94.68 \\
95.56 \\
95.97 \\
97.41\end{array}$ \\
\hline $15-46$ & $\begin{array}{l}1 \\
3 \\
7 \\
14 \\
28\end{array}$ & $\begin{array}{l}3.15 \\
1.69 \\
0.19 \\
1.45 \\
2.12\end{array}$ & $\begin{array}{l}56.85 \\
58.31 \\
59.81 \\
58.55 \\
57.88\end{array}$ & $\begin{array}{l}94.75 \\
97.18 \\
99.68 \\
97.58 \\
96.47\end{array}$ & $\begin{array}{l}14.67 \\
9.01 \\
8.71 \\
7.99 \\
5.10\end{array}$ & $\begin{array}{l}165.33 \\
170.99 \\
171.29 \\
172.01 \\
174.90\end{array}$ & $\begin{array}{l}91.85 \\
94.99 \\
95.16 \\
95.56 \\
97.17\end{array}$ \\
\hline $46-92$ & $\begin{array}{l}1 \\
3 \\
7 \\
14 \\
28\end{array}$ & $\begin{array}{l}2.20 \\
0.99 \\
0.00 \\
1.16 \\
1.27\end{array}$ & $\begin{array}{l}57.80 \\
59.01 \\
60.00 \\
58.84 \\
58.73\end{array}$ & $\begin{array}{l}96.33 \\
98.35 \\
100.0 \\
98.07 \\
97.88\end{array}$ & $\begin{array}{l}10.39 \\
6.48 \\
1.84 \\
4.84 \\
3.40\end{array}$ & $\begin{array}{l}169.61 \\
173.52 \\
178.16 \\
175.16 \\
176.60\end{array}$ & $\begin{array}{l}94.23 \\
96.40 \\
98.98 \\
97.31 \\
98.11\end{array}$ \\
\hline $92-145$ & $\begin{array}{l}1 \\
3 \\
7 \\
14 \\
28\end{array}$ & $\begin{array}{l}0.94 \\
0.28 \\
0.00 \\
0.00 \\
0.00\end{array}$ & $\begin{array}{l}59.06 \\
59.72 \\
60.00 \\
60.00 \\
60.00\end{array}$ & $\begin{array}{l}98.43 \\
99.53 \\
100.0 \\
100.0 \\
100.0\end{array}$ & $\begin{array}{l}3.78 \\
1.97 \\
1.94 \\
1.69 \\
0.85\end{array}$ & $\begin{array}{l}176.22 \\
178.03 \\
178.06 \\
178.31 \\
179.15\end{array}$ & $\begin{array}{l}97.90 \\
98.91 \\
98.92 \\
99.06 \\
99.53\end{array}$ \\
\hline $145-182$ & $\begin{array}{l}1 \\
3 \\
7 \\
14 \\
28\end{array}$ & $\begin{array}{l}1.26 \\
0.00 \\
0.00 \\
0.00 \\
0.00\end{array}$ & $\begin{array}{l}58.74 \\
60.00 \\
60.00 \\
60.00 \\
60.00\end{array}$ & $\begin{array}{l}97.90 \\
100.0 \\
100.0 \\
100.0 \\
100.0\end{array}$ & $\begin{array}{l}6.30 \\
3.94 \\
0.97 \\
0.00 \\
1.27\end{array}$ & $\begin{array}{l}173.70 \\
176.06 \\
179.03 \\
180.00 \\
178.73\end{array}$ & $\begin{array}{l}96.50 \\
97.81 \\
99.46 \\
100.0 \\
99.29\end{array}$ \\
\hline
\end{tabular}


Agric. Biol. J. N. Am., 2013, 4(3): 166-174

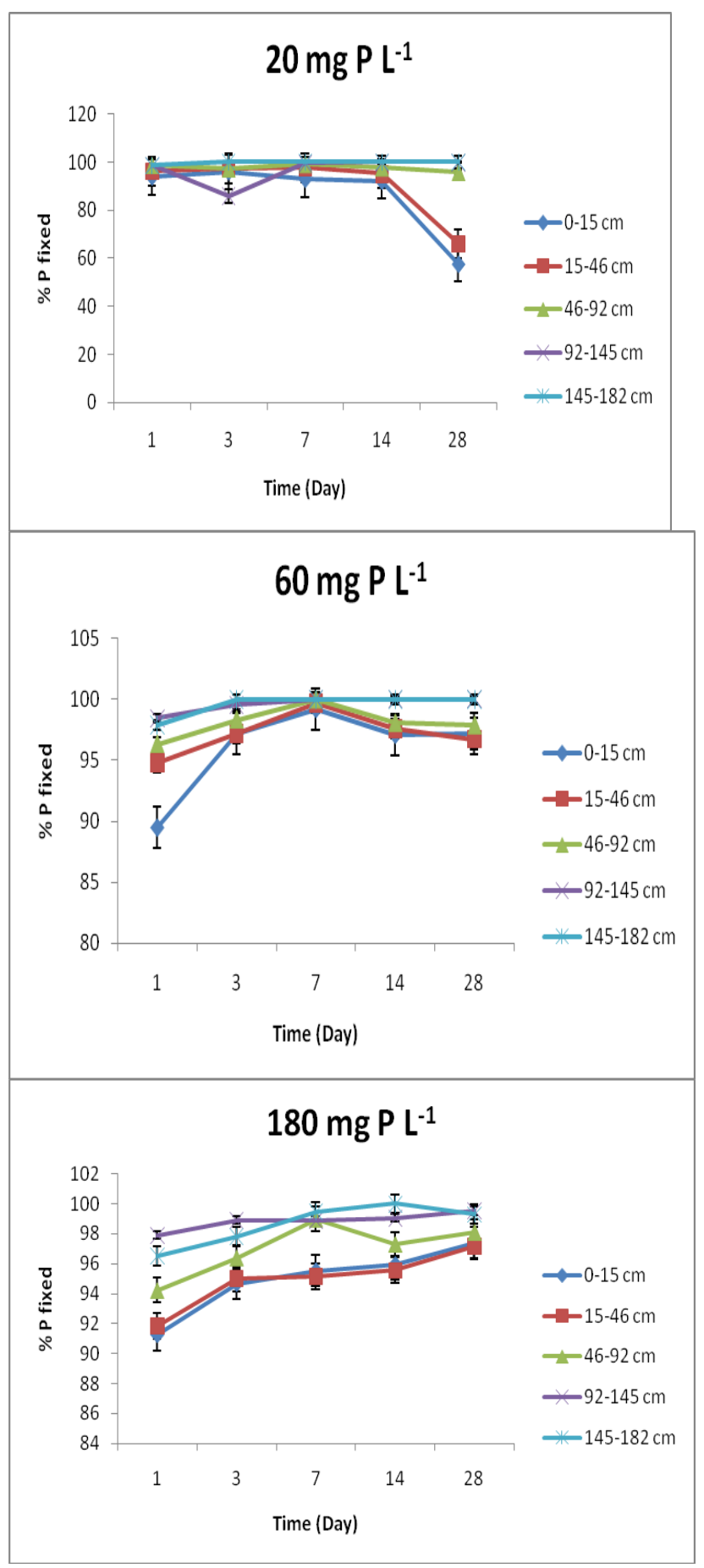

Fig 1. Variation in percent $P$ fixed with time after the addition of different levels of $P$.

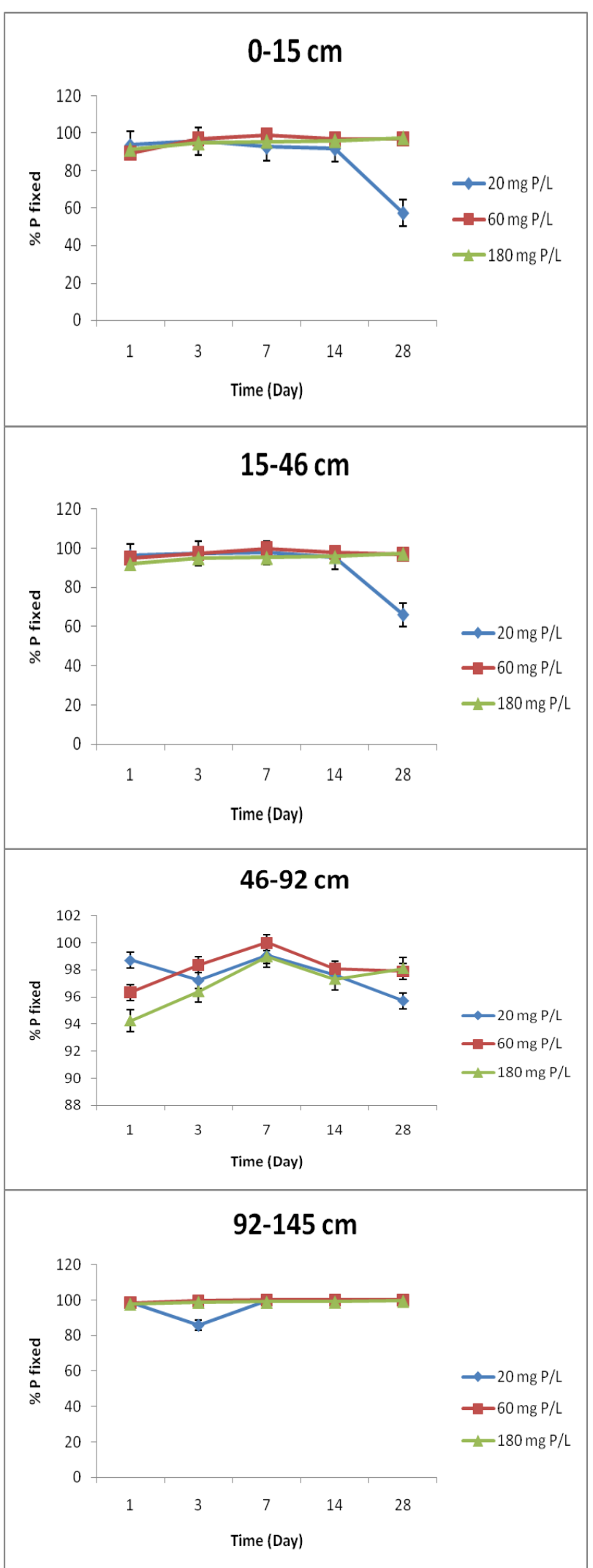




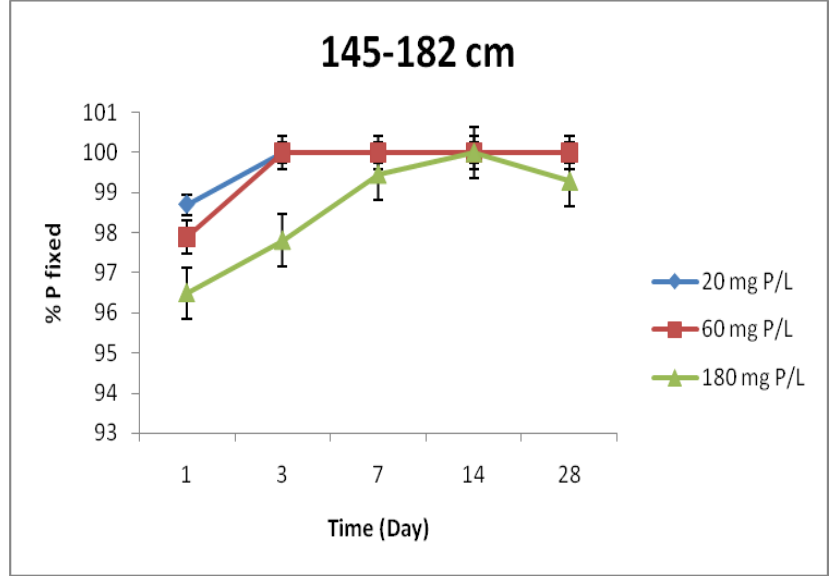

Fig 2. Variation in percent $P$ fixed with time at the different depths.

Harrold and Tabatabai (2006) pointed out that the aliphatic acids containing $\alpha$-carboxyl and $\beta$-hydroxyl functional groups or phenolic acids containing orthohydroxyl groups were more effective in causing the release of $P$ from soils than similar organic acids having other functional group combinations.
Percent $\mathrm{P}$ fixed had a net positive correlation with soil $\mathrm{pH}$ values. This finding was similar to that of Mukwange (1975) who reported that the amount of phosphate adsorbed increased with increase in $\mathrm{pH}$ on soils from the Guinea and Sudan savannah zones of Nigeria. Some researchers found no correlation between $\mathrm{P}$ fixed and $\mathrm{pH}$ (Ayodele and Agboola, 1981; Dodor and Oya, 2000) while others found a negative correlation between $\mathrm{P}$ fixed and $\mathrm{pH}$ (Kanwar and Grewal, 1990; Naidu et al., 1990). The increase in $\mathrm{P}$ fixed with $\mathrm{pH}$ could be associated to the fact that, as $\mathrm{pH}$ goes up from 5.5 to 7.5 , the available phosphorus changes from $\mathrm{H}_{2} \mathrm{PO}_{4}{ }^{-}$to $\mathrm{HPO}_{4}{ }^{2-}$ all of which are available forms of $\mathrm{P}$ (Le Mare, 1991). Mono calcium and mono magnesium phosphates $\left[\mathrm{Ca}\left(\mathrm{H}_{2} \mathrm{PO}_{4}\right)_{2}\right.$ and $\left.\mathrm{Mg}\left(\mathrm{H}_{2} \mathrm{PO}_{4}\right)_{2}\right]$ are water soluble, while the bi substituted $\left[\left(\mathrm{CaHPO}_{4}\right)\right.$ and $\left.\mathrm{Mg}\left(\mathrm{HPO}_{4}\right)\right]$ and tri substituted $\left[\mathrm{Ca}_{3}\left(\mathrm{PO}_{4}\right)_{2}\right.$ and $\left.\mathrm{Mg}_{3}\left(\mathrm{PO}_{4}\right)_{2}\right]$ are poorly soluble (Vopyan, 1984; Le Mare, 1991). Hence, as pH increases more of the poorly soluble calcium and magnesium phosphates are formed and fixation increases.

Table 3. Correlation coefficients $(r)$ between percent $P$ fixed and some soil properties.

\begin{tabular}{|c|c|c|c|c|c|c|}
\hline $\begin{array}{l}\text { Added P } \\
\left(\mathrm{mg} \mathrm{L}^{-1}\right)\end{array}$ & Time (Days) & Organic C & Clay & $\mathrm{pH}$ & $\mathrm{Ca}$ & Available $\mathrm{P}$ \\
\hline \multirow{5}{*}{20} & 1 & $-0.951^{*}$ & $0.655 \mathrm{~ns}$ & $0.782 \mathrm{~ns}$ & $-0.907^{*}$ & -0.755 ns \\
\hline & 3 & $0.060 \mathrm{~ns}$ & $-0.302 \mathrm{~ns}$ & -0.152 ns & $0.214 \mathrm{~ns}$ & $0.345 \mathrm{~ns}$ \\
\hline & 7 & $-0.962^{* *}$ & $0.570 \mathrm{~ns}$ & $0.683 \mathrm{~ns}$ & $-0.973^{* *}$ & -0.722 ns \\
\hline & 14 & $-0.980^{* *}$ & $0.802 \mathrm{~ns}$ & 0.859 ns & $-0.926^{*}$ & $-0.902^{*}$ \\
\hline & 28 & $-0.931^{*}$ & $0.813 \mathrm{~ns}$ & $0.911^{*}$ & $-0.812 n s$ & $-0.855 n s$ \\
\hline \multirow{5}{*}{60} & 1 & $-0.964^{* *}$ & $0.656 \mathrm{~ns}$ & $0.730 \mathrm{~ns}$ & $-0.980^{* *}$ & $-0.803 n s$ \\
\hline & 3 & $-0.901^{\star *}$ & $0.963^{\star *}$ & $0.973^{\star *}$ & -0.736 ns & $-0.982^{\star *}$ \\
\hline & 7 & $-0.949^{*}$ & $0.598 \mathrm{~ns}$ & $0.726 \mathrm{~ns}$ & $-0.935^{*}$ & $-0.721 \mathrm{~ns}$ \\
\hline & 14 & $-0.890^{*}$ & $0.929^{*}$ & $0.896^{*}$ & $-0.801 \mathrm{~ns}$ & $-0.994^{\star \star}$ \\
\hline & 28 & $-0.790 \mathrm{~ns}$ & $0.993^{\star *}$ & $0.953^{* *}$ & $-0.624 n s$ & $-0.985^{\star *}$ \\
\hline \multirow{5}{*}{180} & 1 & $-0.868 \mathrm{~ns}$ & $0.914^{*}$ & $0.903^{*}$ & $-0.790 \mathrm{~ns}$ & $-0.966^{\star *}$ \\
\hline & 3 & $-0.844 \mathrm{~ns}$ & $0.910^{*}$ & $0.887^{*}$ & -0.776 ns & $-0.962^{\star *}$ \\
\hline & 7 & -0.857 ns & $0.855 \mathrm{~ns}$ & $0.957^{* *}$ & $-0.660 \mathrm{~ns}$ & -0.833 ns \\
\hline & 14 & $-0.863 \mathrm{~ns}$ & $0.978^{\star \star}$ & $0.978^{* *}$ & -0.672 ns & $-0.977^{* *}$ \\
\hline & 28 & $-0.821 n s$ & $0.975^{\star \star}$ & $0.943^{*}$ & $-0.687 n s$ & $-0.986^{\star *}$ \\
\hline
\end{tabular}

*Significant at the 0.05 level (2-tailed).

** Significant at the 0.01 level (2-tailed).

ns $=$ not significant at the 0.05 level (2-tailed). 
Percent $\mathrm{P}$ fixed had a net positive correlation with clay content. Similar results were also observed by Ayodele and Agboola (1981). This indicates that fixation increased with increase in amount of clay. This could also be an indication that the soils are made up of aluminosilicate clays of the layered structure (phyllosilicates), which have sites for adsorption of $P$. As the amount of clay increases, the number of fixation sites increases. Fixation of phosphates by phyllosilicate clays could be viewed as surface reaction between exposed $\mathrm{OH}$ groups on the mineral crystal and the $\mathrm{H}_{2} \mathrm{PO}_{4}{ }^{-}$ion or removal of aluminium and iron ions from the edges of the silicate clay crystals for hydroxyl phosphates. Woodruff and Kamprath (1965) found that sandy Ultisols retain much less phosphorus than clayey Ultisols of similar mineralogy.

There was a significant net negative correlation between percent $P$ fixed and available $P$. This was contrary to findings by Dodor and Oya (2000) who found no correlation between $\mathrm{P}$ fixed and available $\mathrm{P}$. This could be associated to the fact that the fixation could mainly be due to adsorption which is a reversible process thus as fixation sites become saturated with $P$, less $P$ is retained.

Correlation between soil properties showed that $\mathrm{pH}$ and clay were highly correlated $(p<0.01 ; r=0.961)$. (Table 4). This could be an indication that clay and $\mathrm{pH}$ are the main properties that control $\mathrm{P}$ fixation in this sub region.

Table 4. Correlation coefficients $(r)$ between selected soil properties and depth.

\begin{tabular}{|l|l|l|l|l|l|l|}
\hline & Organic carbon & Available P & $\mathrm{pH}$ & $\mathrm{Ca}$ & Clay & Sand \\
\hline Available P & $0.856 \mathrm{~ns}$ & - & & & & \\
\hline $\mathrm{pH}$ & $-0.835 \mathrm{~ns}$ & $-0.924^{*}$ & - & & & \\
\hline $\mathrm{Ca}$ & $0.927^{*}$ & $0.734 \mathrm{~ns}$ & $-0.607 \mathrm{~ns}$ & - & & \\
\hline Clay & $-0.750 \mathrm{~ns}$ & $-0.964^{\star *}$ & $0.961^{* *}$ & $-0.548 \mathrm{~ns}$ & - & \\
\hline Sand & $0.885^{*}$ & $0.547 \mathrm{~ns}$ & $-0.519 \mathrm{~ns}$ & $0.940^{*}$ & $-0.372 \mathrm{~ns}$ & - \\
\hline Depth & $-0.956^{* *}$ & $-0.961^{* *}$ & $0.935^{*}$ & $-0.820 \mathrm{~ns}$ & $-0.906^{*}$ & $-0.710 \mathrm{~ns}$ \\
\hline
\end{tabular}

*Significant at the 0.05 level (2-tailed).

** Significant at the 0.01 level (2-tailed).

ns $=$ not significant at the 0.05 level (2-tailed).

Phosphorus fixation capacity could be overcome by the application of $P$ fertilizer at a higher rate or by applying slow releasing $P$ fertilizers as phosphate rocks to have enough $P$ left over for crops to increase productivity. The use of plants with well-developed root systems could also be recommended to ensure that it explores the soil volume more effectively. Transformation of $\mathrm{P}$ in soils is complex, and some of the added $P$ fertilizer which is fixed in the adsorbed state, could be seen as long-term residual $P$ pools for plants. To maximize fertilizer $P$ efficiency especially in the soil, band placement at planting time should be recommended, because the findings of this study show that after one day of incubation more than $90 \%$ of the added $\mathrm{P}$ was fixed.

\section{CONCLUSION}

Soils of the mount Cameroon region have the ability to fix $P$ with the amount fixed increasing with increasing supply of $\mathrm{P}$ and depth. More than $90 \%$ of added $P$ was fixed after one day of incubation. Phosphorus is therefore not a hazard to contaminate groundwater supplies in this sub-region if properly managed. Small applications of $P$ could be made during the growing season for soils with similar characteristics like the upper horizons so as to avoid waste when large amounts are applied but larger quantities could be applied to soils with similar characteristics like the lower horizons.

\section{ACKNOWLEDGMENTS}

The authors wish to acknowledge the financial assistance of the University of Buea and the Institute of Agricultural Research for Development, Ekona. Technical assistance by Mr Isaiah Aboh is gratefully acknowledged.

\section{REFERENCES}

Awad, K.M and AL-Obaidy, K.S (1989). Effect of organic residues on phosphate adsorption by some calcareous soils. Mesopotamia J. Agric. 21: 53 - 67.

Ayodele, $O$ and Agboola, A..A (1981). Evaluation of phosphorus fixation capacity of tropical savannah soils of Western Nigeria. Soil Sci. Soc. Am. J. 45: 462 - 464.

Banik, P., Ghosal, P.K., Sasmal, T.K., Bhattacharya, S., Sarkar, B.K and Bagchi, D.K (2006) Effect of organic and inorganic nutrients for soil quality conservation and yield of rainfed low land rice in sub tropical plateau region. J. Agron. Crop Sci. 192: 331- 343.

Brady, N.C (1984). The nature and properties of soils. Macmillan Publishing Company, NY, USA. 
Brouwere, K.D., Thijs, A., Hens, M and Merckx, R (2003). Forms and availability of soil phosphorus in temperate forests in southern Chile and Flanders. Gayana Botánica. 60: 17-23.

Dhargawe, G.N., Mattur, D.B., Babulka, P.S., Kene, D.R and Borkar, D.K (1991). Availability of soil phosphorus as affected by organic matter. J. Soils Crops 1: 142 - 146.

Dodor, D.E and Kazuhro, O (2000). Phosphate sorption characteristics of major soils in Okinawa, Japan. Commun. Soil Sci. Plant. Anal. 31: 277-288.

Dolui, A.K and Gangopadhyay, S.K (1984). Fixation of phosphate in relation to properties of some red and lateritic soils of West Bengal. Indian J. Agric. Chem. 17: $177-182$.

Donuhue, R L., Shickling, J. C and Robertson, L (1971). Soil: An Introduction to Soils and Plant Growth, John Wiley and Sons, Inc, NY, USA.

Doula, M., loannou, A and Dimirkou, A (1996). Thermodynamics of phosphate adsorption-desorption by alfisols, entisols, vertisols, and inceptisols. Commun. Soil Sci. Plant Anal. 27: 1749-1764.

Foth, H.D (1984). Fundamentals of Soil Science. John Wiley and Sons, Inc. NY, USA.

Ghosal, P., Chakraborty, T and Banik, P (2011). Phosphorus fixing capacity of the Oxic Rhodustalf- alfisol soil in the Chotanagpur plateau region of Eastern India. Agric. Sci. 2: 487-490.

Harrold, S.A and Tabatabai, M.A (2006). Release of inorganic phosphorus from soils by low-molecular-weight organic acids. Commun. Soil Sci. Plant Anal. 37: 1233-1245.

Hedley, M.J., Stewart, J.W.B Chauhan, B.S (1996). Changes in organic soil phosphorus fractions induced by cultivation practices and by laboratory incubations, Soil Sci. Soc. Am. J. 46: 970-976.

lyamuremye, F and Dick, R. P (1996). Organic amendments and phosphorus sorption by soils. Adv. Agron. 56: 139185.

Jackson, M.L (1958). Soil chemical analysis. Printice-Hall, Inc., Englewood Cliffs, NJ, USA.

Juo, A.S.R. and Fox, R.L. (1977) Phosphate sorption characteristics of some Bench Mark soils of West Africa. Soil Sci. 124: 370-376.

Kanwar, J.S and Grewal, J (1990). Phosphorus fixation in Indian soils. $2^{\text {nd }}$ edition. New Delhi, India: Indian Council of Agricultural Research.

Koenig, R.T., Barnhill, J.V and Hurst, C.J (2000). Sampling depth effects on sodium bicarbonate $\left(\mathrm{NaHCO}_{3}\right)$ extractable phosphorus and potassium and fertilizer recommendations. Commun. Soil Sci. Plant Anal. 31: 375-386.

Le Mare, P. H (1991). Rock Phosphate in Agriculture. Exp. Agric. 27: 413-422.

Morel, J.L., Fardeau, J.C., Beruff, M.A and Guckert, A (1989). Phosphate fixing capacity of soils: a survey using the isotopic exchange technique of soils from north-eastern France. Fert. Res. 19: 103 - 111.

Mukwange, $\mathrm{U}$ (1975). The Influence of $\mathrm{pH}$ on the adsorption of phosphate by soils from the Guinea and Sudan Savannah zones of Nigeria. Soil Sci. Soc. Am. Proc. 39: 11001102.

Murphy, J and Riley, J.P (1962). A modified single solution method for the determination of phosphate in natural waters, Anal. Chim. Acta $27: 31-36$.

Naidu, R., Syers, J.K., Tillman, R.W and Kirkman, J.H (1990). Effect of liming on phosphate soption by acid soils. J. Soil Sci. 41: 163 - 175.

Ngane, E.B., Tening, A.S., Ehabe, E.E and Tchuenteu, F (2012). Potentials of some cement by-products for liming of an acid soil in the humid zone of South-western Cameroon. Agric. Biol. J. N. Am. 3: 326-331.

Owusu-Bennoah, E and Acquaye, D.K (1989). Phosphate sorption characteristics of selected major Ghanaian soils. Soil Sci. 148: 114 - 123.

Pardon, M.T and Guadalix, M. E (1990). Phosphate sorption in allophanic soils and release of sulphate, silicate and hydroxyl J. Soil Sci. 4: 607-612.

Quang, V.D., Thai, V.C., Linh, T.T.T and Dufey, J.E (1996). Phosphorus sorption in soils of the Mekong Delta (Vietnam) as described by the Langmuir equation. Eur. J. Soil Sci. 47: 113-123.

Sanchez, P.A (1976). Properties and management of soils in the tropics. John Wiley \& Sons. NY, USA.

Sanchez, P.A and Salinas, J.G (1981). Low input technology for managing oxisols and ultisols in tropical America. Adv. Agron. 34: 279-406.

Sattell, R.R and Morris, R.A (1992). Phosphorus fractions and availability in Sri Lankan alfisols. Soil Sci. Soc. Am. J. 56: 1510-1515.

Soon, Y.K (1990). Solubility and retention of phosphate in soils of north western Canada prairie. Can. J. Soil Sci. 70: 227 $-237$.

Sparks, D.L (1995). Environmental Soil Chemistry. Academic Press, San Diego, USA.

Subramanian, K.S and Kumaraswamy, K (1989). Effect of continuous cropping and fertilization on the phosphate fixation capacity of soil. J. Indian Soc. Soil Sci. 37: 682686.

Tening, A.S., Tchuenteu, F and Gwanpua, P. P (2008). Suitability of different extractants and turbidimetric reagents in the quantitative determination of sulphatesulphur in soils of South-western Cameroon. J. Cameroon Academy Sci. 7: 157-162.

Vopyan, V. G (1984). Agricultural Chemistry 1. Mir Publishers, Moscow.

Woodruff, J,R and Kamprath, E.J (1965). Phosphorus adsorption maximum as measured by Langmuir Isotherm and its relationship to phosphorus availability. Soil Sci. Soc. Am. Proc. 29: 148 - 280. 